\title{
Behavioral and Climate Change on Fish Nematology
}

\section{Mamatha $\mathbf{P}$ and Ramachandra Mohan $\mathbf{M}^{*}$}

Department of Zoology, Lake Water quality research Laboratory, Bangalore University, Bangalore- 560 056, India

\begin{abstract}
The impact of fish nematode on gill histopathologyl and damages are predominate in their filaments, primary lamellae, degeneration of epithelium, inter lamellar epithelium and clumping of RBCs. Results of present study on fish, Glossogobius giuris indicates that there was parasites in gill, Further studies are made to understand in terms of metacercariae in fish tissues like gill of naturally available and highly proteinaceous fish, in Cauvery delta region. Fish gills are continuously exposed to water for gaseous exchange, during this there was a possible contact of Trematode parasites. The major any favorable conditions to enhance the incidence of Trematoda parasites and water chemistry like $\mathrm{pH}, \mathrm{DO}, \mathrm{BOD}$ and $\mathrm{COD}$ along with the temperature have any role for abundance of fish parasites. Variations in temperature with $3-4^{\circ} \mathrm{C}$ are seems to be favorable for behavioral and climate change on fish nematology.
\end{abstract}

Keywords: Metacercariae; Nematology; Fish-borne trematodes

\section{Introduction}

High quality protein is provided by Fishes, but a threat is posed by infectious parasites to fish culture. Due to infectious parasites, particularly trematodes, not only causes economic loss to farmers and also results in zoonosis. These infections are caused by eating raw or, improperly cooked or processed fish. It is the main source causing human laryngitis that has been reported from various geographical regions. Currently the number of people infected with fish-borne trematodes is not less than 18 million as per the World Health Organization (WHO).

The complex life-cycle of the gill trematode involves a bird (or mammal) host, the first intermediate snail host, and an intermediate fish host. Metacercaria enters bird, when fish is eaten and releases cyst into the intestinal tract of definitive host and matures into an adult worm when it attaches to gut epithelium. And after a few days it produces eggs which shed into the host's lumen and then defecated into the water. When trematode egg is released Snail eats and then hatches, releases the miracidium larva. The germinal cells of miracidium, ultimately develops into a redia larva. It asexually produces large numbers of the cercaria larva and is shed into water. It is passively engulfed by fish or penetrates into it. The cercaria occupies a cartilage which supports in the gill filament and develops into an encysted metacercaria and becomes encapsulated. It can harm gills and fish host. Metacercaria exhibiting cartilaginous encapsulation.

The Blazer and Gratzek recognized the destructive nature of the trematode [1] and Vogelbein and Overstreet [2] who described the damage to the gills that resulted from the trematode infection. The metacercaria stage infects the gills of many fish species and occasionally the intestinal wall and muscles of frogs Rana sps. [3].

\section{Pathology of the Gill Trematode}

Trematodes cause harm to their fish hosts. Mechanical damage is caused due to the migration of cercariae through host tissues [4] and it also modify host behavior and improves the chance of fish being eaten by a vertebrate host [5]. In fish, rarely heavy trematode infections results in serious tissue displacement, secondary bacterial infection, and death $[5,6]$.

Some of the trematodes produces alterations in the gills of many freshwater fishes $[7,8]$. Within an hr, the cercaria occupies next to the gill filament cartilage after infection [1]. An inflammatory response produced by the parasite induces proliferation of host fibroblasts that differentiates into chondroblasts and then chondrocytes which forms a cartilaginous encapsulation around the parasite [1,2]. The encapsulation may incorporate more than one cyst. The encapsulation continues to thicken, ultimately destroys the normal gill architecture and reduces the surface area of the respiratory epithelium. Further gill function is compromised by an influx of other inflammatory cells, including macrophages, eosinophils, heterophils, and lymphocytes [1]. Avian hosts are highly mobile and as such it is very difficult to manage the same in parasites. And human intervention, spreading infected fish and snails, and many different fish species are susceptible. The most practical approach is necessary to treat and prevent the further spread of this very prolific and hardy exotic snail.

The present study was undertaken to establish Trematoda parasites in Mandya district of Cauvery belt to find out parasitic infection in edible fish, Glossogobius giuris.

\section{Materials and Methods}

Fish, Glossogobius giuris collected from Cauvery basin of Mandya district during post monsoon and were acclimatized in the laboratory for further investigation. 125 fish and a couple of fish were found to be infected and these fish are dissected between 7 and 14 days and gills were extracted. The gill tissue of the infected fish were immediately washed and fixed in $10 \%$ neutral buffered formalin processed further and were embedded in paraffin wax of $56-58^{\circ} \mathrm{C}$ and serial section of 4-6 micrometer thickness [9] were cut, stained in Haematoxylin and counter stained with Eosin. The DPX mounted sections were examined under light microscopy and taken photographs by using a Research Microscopic camera.

\section{Results and Discussion}

There are five pairs of gills in the fish, Glossogobius giuris, each of which consists of large lower and shorter upper limbs with ceratobranchial and epibranchials respectively. Gill rakers are present in two rows on the inner margin of each gill arch. The gill rakers are teeth like which form a sieve to filter the water, and protect the delicate

*Corresponding author: Ramachandra Mohan, Department of Zoology, Lake Water Quality Research Laboratory, Bangalore University, Bangalore- 560056, India, Tel: 080-2214001; E-mail: mohanramachandr@gmail.com

Received September 02, 2014; Accepted October 07, 2014; Published October 15,2014

Citation: Mamatha P, Ramachandra Mohan M (2014) Behavioral and Climate Change on Fish Nematology. J Fisheries Livest Prod 2: 121. doi: 10.4172/23322608.1000121

Copyright: (c 2014 Mamatha P, et al. This is an open-access article distributed under the terms of the Creative Commons Attribution License, which permits unrestricted use, distribution, and reproduction in any medium, provided the original author and source are credited. 
gill filaments from solid particles. Each gill arch is enclosed with an afferent and efferent branchial vessel and nerves. It consists of a thick epithelium with large number of mucous glands, eosinophilic cells and taste buds externally. Further the gill consists of laterally compressed leaf like gill filaments (primary gill lamellae) arranged alternatively on either side of the interbranchial septum. Each primary filament bears a row of secondary lamellae on both sides perpendicular to its long axis comprising of a central core of cartilaginous rod with lining of epithelial cells and blood vessels. The lamellae are covered by an epithelium usually encased by primary epithelium or gill filament epithelium and consist of mucus secreting cells and chloride cells.

\section{Lamellae}

Each primary lamella bears a large number of secondary lamellae on both sides. These flat, leaf like structures are the main seats of gaseous exchange. Generally the secondary lamellae are free from each other but may be fused at the distal ends of the primary lamellae. Secondary lamella consists of a central vascular core composed of pillar cells covered by a basement membrane and an outer epithelium.

Comparative studies were made during Monsoon periods; interestingly post Monsoon season was proven more incidence due to stagnation of water. Further studies are made to understand in terms of any favorable conditions to enhance the incidence of Trematode parasites and water chemistry like $\mathrm{pH}, \mathrm{DO}, \mathrm{BOD}$ and COD along with the temperature have any role for abundance of fish parasites (Table 1 ). The studies on water quality parameters were made [10] and the histological and anatomy of fish gill were done by P. Mamatha and M. Ramachandra Mohan [11]. Reduction of DO an Increase of TDS and COD may influence the abundance of Parasite population. These results are coinciding with [12]. The Trematode infection affects feeding habit, acquisition of body weight and even death of the host fish.

\section{Gill histopathology}

Histology of gill of control fish exhibits no histopathological alterations. Normal appearance of primary and secondary lamellae (Figure 1). Abnormal appearance of primary and secondary lamellae (Figure 2), on the other hand edema noticed in gill filaments of Glossogobius giuris, fish were sacrificed between 7 days to 14 days depends health of fish (Figure 3). The major histopathological observations are Degeneration in epithelium and interlamellar epithelium, Vacuoles along with clumping of RBCs, Lifting of epithelium in secondary lamellae due to Trematode Meta cercarians habitate in fish gill filaments which are measured 350 microns and length of $350 \mathrm{~mm}$ and width of $60 \mathrm{~mm}$ (Figure 4).

In the contrast when compared to Monsoon the post Monsoon is favorable for multiplication of Metacercaria Parasites, otherwise drip in temperature and DO values and increase in COD and BOD levels contribute further increase of incidence of Metacercaria, Parasites of fish Glossogobius giuris.

\begin{tabular}{|c|c|c|c|c|}
\hline SI. No & PARAMETERS & UNITS & WHO STANDARD & MADDUR CANAL \\
\hline $\mathbf{1}$ & $\mathrm{Ph}$ & -- & $6-9$ & $8.0 \pm 0.15$ \\
\hline $\mathbf{2}$ & Temperature & ${ }^{\circ} \mathrm{C}$ & -- & $26 \pm 3.09$ \\
\hline $\mathbf{3}$ & Chloride & $\mathrm{mg} / \mathrm{l}$ & $200-400$ & $560 \pm 78.12$ \\
\hline $\mathbf{4}$ & Total Alkalinity & $\mathrm{mg} / \mathrm{l}$ & $200-600$ & $545 \pm 70.12$ \\
\hline $\mathbf{5}$ & Total Hardness & $\mathrm{mg} / \mathrm{l}$ & 500 & $744 \pm 9.35$ \\
\hline $\mathbf{6}$ & DO & $\mathrm{mg} / \mathrm{l}$ & $5-10$ & $6.00 \pm 1.18$ \\
\hline $\mathbf{7}$ & COD & $\mathrm{mg} / \mathrm{l}$ & 10 & $63 \pm 0.75$ \\
\hline $\mathbf{8}$ & BOD & $\mathrm{mg} / \mathrm{l}$ & $8-10$ & $12 \pm 0.78$ \\
\hline
\end{tabular}

Table 1: Table showing results of physicochemical parameters.

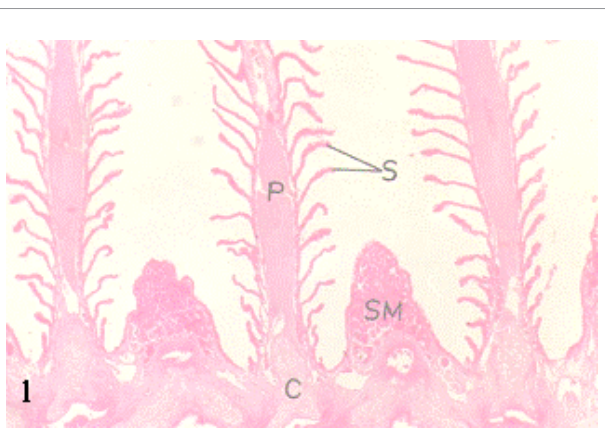

Figure 1: Sagittal section showing gill histology in control. Normal appearance of primary $(\mathrm{P})$ and secondary lamellae (S). H\&E (100 X).

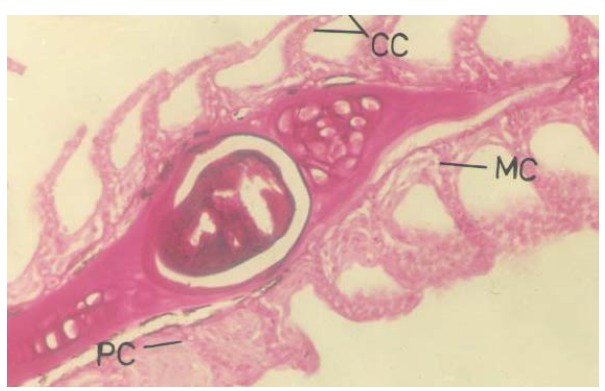

Figure 2: Gill of Fish G giuris showing ,Histopathological alteration of gill filaments brought by A Trematode, Metacercaria, and Parasites of fish Glossogobius giuris showing in secondary lamellae, regeneration of chloride cells (ROC) and fewer Vacuoles. (100X).

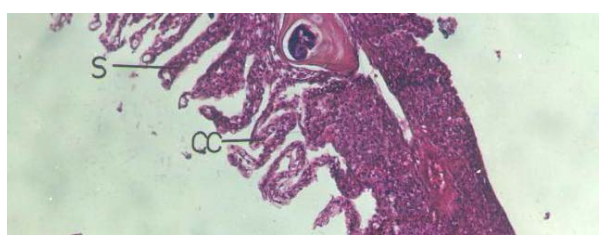

Figure 3: Gill of Fish G giuris showing Curling of Secondary lamella (CSL), prominent pillar cell (PC), telengiectasia (TL), Deformities in mucus cell (DC), formation of heavy vacuoles in mucus cells (MC), Clumping of Blood vessels $(\mathrm{RBC})$ and in primary lamella degenerative process are brought by $A$ Trematode , Metacercaria, Parasites (100X).

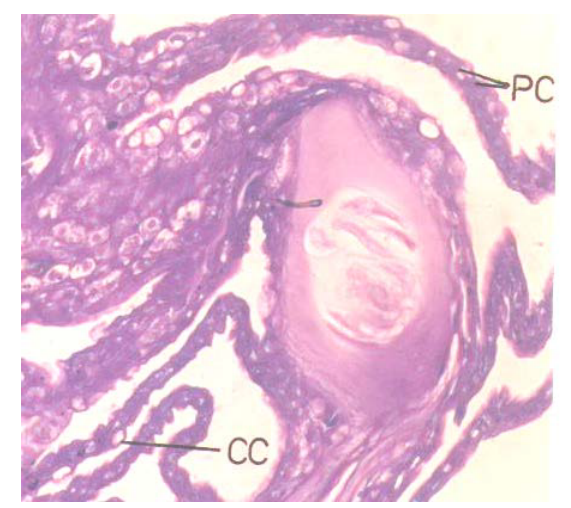

Figure 4: Gill of Fish G giuris showing Trematode, metacercaria, in the secondary lamellae. Regeneration in its gills and chloride and pillar cells were vacuolated. (100X). 


\section{Conclusion}

The inland freshwater fisheries resources of India are suffering similar consequences from the conflict between economic growth and biodiversity conservation. A serious Habitat Loss, impact of Pollution, Alien Invasive Species, lach of Water Management and Urban Development variation of climate change, Natural Habitat Change and patterns of Aquaculture are main cause. Therefore eventually fisheries Resources will continue to be threatened, at an increasing rate, as long as the Indian economy continues to grow, ensuring the Competitive exclusion of fishes and other aquatic species

\section{References}

1. Blazer VS, Gratzek JB (1985) Cartilage proliferation in response to metacercarial infections of fish gills. Journal of Comparative Pathology 95: 273-280.

2. Vogelbein WK, Overstreet RM (1988) Life-history and pathology of a heterophyid trematode infecting Florida-reared ornamental fishes. International Association for Aquatic Animal Medicine Proceedings.

3. Salgado-Maldonado G, Rodriguez-Vargas MI, Campos-Perez JJ (1995) Metacercariae of Centrocestus formosanus (Nishigori, 1924) (Trematoda) in freshwater fishes in Mexico and their transmission by the thiarid snail Melanoidestuberculata. Studies on Neotropical Fauna and Environment 30: 245-250.

4. Hoffman GL (1999) Parasites of North American freshwater fishes, (2nd edn.) Comstock Publishing Associates, Cornell University Press, Ithaca, New York.

5. Overstreet RM, Curran SS (2004) Defeating diplostomoid dangers in USA catfish aquaculture. Folia Parasitologica 51: 153-165.

6. Mitchell AJ, Smith CE, Hoffman GL (1982) Pathogenicity and histopathology of an unusually intense infection of white grubs (Posthodiplostomum m. minimum) in the fathead minnow (Pimephales promelas). Journal of Wildlife Diseases 18: $51-57$

7. Mitchell AJ, Salmon MJ, Huffman DG, Goodwin AE, Brandt TM (2000) Prevalence and pathogenicity of a heterophyid trematode infecting the gills of an endangered fish, the fountain darter, in two central Texas spring-fed rivers. Journal of Aquatic Animal Health 12: 283-289.

8. Mitchell AJ, Goodwin AE, Salmon MJ, Brandt TM (2002) Experimental infection of an exotic heterophyid trematode, Centrocestus formosanus, in four aquaculture fishes. North American Journal of Aquaculture 64: 55-59.

9. Mohan M (1991) Experimental Studies on the Hypothalamo Hypophysea Ovarian System of Fresh Water Gobiid Fish, Glossogobius Giuris (Ham).

10. Krishna Ram HK, Ramachandra Mohan M, Chithanagiri, Latha N (2008) Water Quality studies on Freshwater Lakes of Kolar Taluk, Kolar, and Karnataka. Environmental Issues and Solutions.

11. Mamatha P, Ramachandra Mohan M (2013) Impact of nualgi on histopathological alteration in the gills of fish, Glossogobius giuris (ham) brought by Neem oil. Poll Res. 32: 457-465.

12. Ram HK, Mohan MR (2008) Nutrient Overloading of a Few Lakes in Bangalore, Karnataka, India
Citation: Mamatha P, Ramachandra Mohan M (2014) Behavioral and Climate Change on Fish Nematology. J Fisheries Livest Prod 2: 121. doi: 10.4172/2332 2608.1000121
Submit your next manuscript and get advantages of OMICS Group submissions

Unique features:

- User friendly/feasible website-translation of your paper to 50 world's leading languages

Audio Version of published paper

Digital articles to share and explore

Special features:

350 Open Access Journals

30,000 editorial team

21 days rapid review proces

- Quality and quick editorial, review and publication processing

- Indexing at PubMed (partial), Scopus, EBSCO, Index Copernicus and Google Scholar etc

- Sharing Option: Social Networking Enabled

- Authors, Reviewers and Editors rewarded with online Scientific Credits

Submit your manuscript at: http://www.omicsonline.org/submission/ 